\title{
Projections of aridity and its regional variability over China in the mid-21st century
}

\author{
Yunhe Yin, ${ }^{\mathrm{a}}$ Danyang Ma, ${ }^{\mathrm{a}, \mathrm{b}}$ Shaohong $\mathrm{Wu}^{\mathrm{a} *}$ and Tao Pan ${ }^{\mathrm{a}}$ \\ ${ }^{a}$ Key Laboratory of Land Surface Pattern and Simulation, Institute of Geographic Sciences and Natural Resources Research, Chinese Academy of \\ Sciences, Beijing, People's Republic of China \\ ${ }^{\mathrm{b}}$ College of Resources and Environment, University of Chinese Academy of Sciences, Beijing, People's Republic of China
}

\begin{abstract}
The effects of aridity on ecosystems and water cycles are pronounced and have received considerable attention. However, aridity changes due to future warming and its regional variability over China remain uncertain. This paper aims to identify the spatiotemporal variations in aridity and its key influencing factors over China in the mid-21st century based on five general circulation models (GCMs) and four representative concentration pathway (RCP) scenarios. An aridity index (AI), defined as the ratio of reference evapotranspiration $\left(E T_{\mathrm{o}}\right)$ to precipitation $(P)$, was calculated. We show that the GCM ensemble means are able to reproduce the variation of aridity during the baseline period. Generally, $E T_{\mathrm{o}}$ anomalies are consistently positive. Other than for the RCP2.6 low-emission scenario, precipitation and aridity are both projected to increase. There are pronounced regional differences in aridity changes; i.e. wetter across most of western China and drier across most of eastern China in the mid-21st century. Negative $A I$ anomalies in western China can be attributed mainly to the projected increase in precipitation. In eastern China, the $A I$ was higher despite positive precipitation anomalies, due mainly to the greater effect of climate change on increasing atmospheric moisture demand. This suggests that evapotranspiration demand should be incorporated into aridity changes under future warming.
\end{abstract}

KEY WORDS aridity; China; regional variability; climate models; evapotranspiration

Received 29 June 2014; Revised 20 January 2015; Accepted 22 January 2015

\section{Introduction}

Greenhouse gas and aerosol emissions have a pronounced effect on global climate. Climate scenarios project an increase in the global mean surface temperature of $0.3^{\circ} \mathrm{C}$ to $4.8^{\circ} \mathrm{C}$ for the period $2081-2100$ relative to $1986-2005$ (IPCC, 2013), and regional and global changes in moisture conditions related to climate change have received considerable attention. Drier or wetter conditions caused by global warming can be identified by capturing the changes in the background aridity rather than temporary anomalies such as droughts (Sherwood and Fu, 2014). Increased aridity is linked to changing biogeochemical cycles, and could negatively affect key ecosystem functions and services (Delgado-Baquerizo et al., 2013). For example, if aridity continues to increase in the future, trees will experience substantially reduced growth (Williams et al., 2010). Moreover, changing aridity may affect the global water balance; have a significant influence on runoff (Arora, 2002); and cause anomalies in the intensity, spatial extent, and frequency of droughts (Nastos et al., 2013). However, the impact of climate change on aridity over the land surface is complex. To address this complexity, it is necessary

\footnotetext{
* Correspondence to: S. Wu, Key Laboratory of Land Surface Pattern and Simulation, Institute of Geographic Sciences and Natural Resources Research, Chinese Academy of Sciences, No. 11 A, Datun Road, Anwai, Beijing 100101, People's Republic of China. E-mail: wush@igsnrr.ac.cn
}

to recognize projected changes in aridity over different spatial-temporal scales.

Studies of the impact of climate change on aridity during the 21 st century have predicted increased aridity over most tropical and mid-latitude land regions (Feng and Fu, 2013), specifically over most of Africa, the Americas, Australia, Southeast Asia, and the Mediterranean region (Gao and Giorgi, 2008; Dai, 2011). Changes in aridity are influenced by many complex factors. Surface aridity is sensitive to rising temperatures, and the effects of increased temperatures on aridity will be exacerbated if precipitation decreases (McCabe and Wolock, 2002). Overall, surface aridity is controlled by the balance between precipitation, $P$ (atmospheric supply), and reference evapotranspiration, $E T_{\mathrm{o}}$ (atmospheric demand) (Budyko, 1974; Middleton and Thomas, 1992; Wu et al., 2006; Sherwood and Fu, 2014). $E T_{\mathrm{o}}$ is an expression of the evaporative power of the atmosphere at a specific location and time of year (Allen et al., 1998), and it is an important indicator of aridity besides precipitation. Generally, aridity will increase in a specific region as $P$ decreases and $E T_{\mathrm{o}}$ increases.

Widespread and significant decreasing trends in $E T_{\mathrm{o}}$ have been observed during the past half-century at regional to continental scales (Peterson et al., 1995; Golubev et al., 2001; Roderick and Farquhar, 2002; Liu et al., 2004; Xu et al., 2006; Dolman and de Jeu, 2010; Yin et al., 2010), and analysis of global aridity trends shows that severe and widespread droughts are likely to occur in the next 
30-90 years over many land areas due to either decreased precipitation and/or increased evaporation (Dai, 2013). Future projections in $E T_{\mathrm{o}}$ are therefore important in terms of reducing uncertainty in aridity assessments. Moreover, as $E T_{\mathrm{o}}$ is not routinely calculated by climate models, its uncertainties have been largely ignored in climate change impact assessments (Prudhomme and Williamson, 2013). Therefore, improving our understanding of changes in $E T_{\mathrm{o}}$ is an important step towards improving confidence in future climate change assessments (Kingston et al., 2009).

Recently in China, there have been several studies to identify future changes in precipitation and evapotranspiration with climate models (e.g. Shi et al., 2007; Gu et al., 2012; Wang et al., 2013; Chen and Frauenfeld, 2014; Wang and Chen, 2014; Xing et al., 2014; Xu et al., 2014). However, most studies on future $E T_{\mathrm{o}}$ have been conducted at local area or basin, thus the regional differences and pattern of future changes in evapotranspiration have been poorly understood over China. Undertaking regional variability assessments is important to reveal detailed impacts of climate change, particularly on agriculture crop production (Izaurralde et al., 2003; Eitzinger et al., 2013) and hydrological cycle (Held and Soden, 2006; Roderick et al., 2014). This highlights the need to investigate the regional variability of projected evapotranspiration and aridity changes over China, as it is characterized by various climate zones from cold temperate in the north to tropical in the south, and from humid in the east to arid in the west.

Furthermore, seldom studies have colligated $E T_{\mathrm{o}}$ to evaluate aridity which is much more complex responding to climate change over China. Wang and Chen (2014) explored the climatological droughts in the future in China using the Palmer Drought Severity Index. However, it was based on Thornthwaite method $E T_{0}$, which may be overestimated by excluding cloud cover and vapour pressure deficit in the parameterization (Wang and Chen, 2014). In the present study, we propose the Penman-Monteith model to estimate $E T_{\mathrm{o}}$.
In addition, aridity changes under the representative concentration pathways (RCPs) (Moss et al., 2010) have been poorly quantified. RCPs were used in the Intergovernmental Panel on Climate Change (IPCC) Fifth Assessment Report (IPCC, 2013) to investigate the impact of greenhouse gases on climate change. In consequence, here we use the four RCP projections to evaluate the regional variability of future aridity changes by incorporating both atmospheric water demand and supply dynamics. The present study has importance and significance for understanding water cycles and planning optimized adaptation schemes for ecosystem and agriculture management response to climate change.

In this study, regional variability of projected changes in aridity over China in the mid-21st century are analyzed using various RCP projections. The major objectives of this study are: (1) to evaluate the performance of climate models in reproducing the spatial and temporal variability of aridity over China during the recent historical period; (2) to access temporal changes in aridity under various RCPs relative to 1981-2010; and (3) to identify regional differences in aridity and the key climatic factors that influence these differences.

\section{Materials and methods}

\subsection{Future climate projections}

Simulated climate projections from 1950 to 2099 were acquired from five GCMs (HadGEM2-ES, IPSL-CM5A-LR, GFDL-ESM2M, MIROC-ESMCHEM, and NorESM1-M) (Table 1), participating in the Coupled Model Intercomparison Project Phase 5 (CMIP5) experiment (Taylor et al., 2012). The outputs of the GCMs were downscaled to $0.5^{\circ}$ and bias-corrected by the Inter-Sectoral Impact Model Intercomparison Project (ISI-MIP) (Hempel et al., 2013; Warszawski et al., 2014). Time-evolving land cover was included for the first time in the suite of CMIP5 long-term experiments (Taylor et al.,

Table 1. General circulation models used in this study.

\begin{tabular}{|c|c|c|c|}
\hline Model name & Modelling centre & $\begin{array}{l}\text { Original resolution } \\
\text { (latitude } \times \text { longitude) }\end{array}$ & Main references \\
\hline GFDL-ESM2M & $\begin{array}{l}\text { NOAA Geophysical Fluid Dynamics } \\
\text { Laboratory, USA }\end{array}$ & $2.0^{\circ} \times 2.5^{\circ}$ & Dunne et al. (2012) \\
\hline HadGEM2-ES & $\begin{array}{l}\text { Met Office Hadley Centre (additional } \\
\text { HadGEM2-ES realizations contributed } \\
\text { by Instituto Nacional de Pesquisas } \\
\text { Espaciais), UK }\end{array}$ & $1.25^{\circ} \times 1.875^{\circ}$ & Collins et al. (2011) \\
\hline IPSL-CM5A-LR & Institut Pierre-Simon Laplace, France & $1.875^{\circ} \times 3.75^{\circ}$ & Dufresne et al. (2013) \\
\hline MIROC-ESM-CHEM & $\begin{array}{l}\text { Model for Interdisciplinary Research } \\
\text { On Climate, Atmosphere and Ocean } \\
\text { Research Institute of The University of } \\
\text { Tokyo, National Institute for } \\
\text { Environmental Studies, and Japan } \\
\text { Agency for Marine-Earth Science and } \\
\text { Technology, Japan }\end{array}$ & $2.8^{\circ} \times 2.8^{\circ}$ & Watanabe et al. (2011) \\
\hline NorESM1-M & Norwegian Climate Centre, Norway & $1.875^{\circ} \times 2.5^{\circ}$ & Bentsen et al. (2013) \\
\hline
\end{tabular}


2012). A statistical bias correction approach was applied to the ISI-MIP dataset to preserve the absolute or relative trends in simulated daily climate data. This approach uses a constant offset or multiplicative correction factor that corrects for long-term differences between simulated and observed monthly mean data in the historical period (Hempel et al., 2013). These five GCMs have driven global hydrological and land-surface models to assess water resources (Davie et al., 2013; Schewe et al., 2014), and meet the data requirement to estimate $E T_{\text {o }}$ using Penman-Monteith model in the present study.

The bias-corrected daily variables from the GCMs, including the average, maximum, and minimum temperatures $(\mathrm{K})$; precipitation $\left(\mathrm{kg} \mathrm{m}^{-2} \mathrm{~s}^{-1}\right)$; shortwave downwelling radiation $\left(\mathrm{W} \mathrm{m}^{-1}\right)$; near-surface wind speed $\left(\mathrm{m} \mathrm{s}^{-1}\right)$; and relative humidity $(\%)$ on a horizontal grid with a $0.5^{\circ} \times 0.5^{\circ}$ resolution are used to simulate $E T_{\text {o }}$ and aridity. Wind speed measured $2 \mathrm{~m}$ above the surface is required for evapotranspiration calculations, so wind speed data from a height of $10 \mathrm{~m}$ was adjusted to the standard height of $2 \mathrm{~m}$ using a logarithmic wind-profile relationship (Allen et al., 1998).

This study analyzes changes in aridity under the RCP2.6, RCP 4.5, RCP 6.0, and RCP 8.5 climate projections. Four pathways were produced that led to radiative forcing levels of 2.6, 4.5, 6.0, and $8.5 \mathrm{~W} \mathrm{~m}^{-2}$ by 2100 (Moss et al., 2010). RCP8.5 is the highest pathway with a radiative forcing of around $8.5 \mathrm{~W} \mathrm{~m}^{-2}$ in 2100 , equivalent to an atmospheric $\mathrm{CO}_{2}$ concentration of approximately $1370 \mathrm{ppm}$ (Moss et al., 2010). By 2100, projected global mean surface temperature increases range from $1.5^{\circ} \mathrm{C}$ for the lowest-emission RCP to $4.5^{\circ} \mathrm{C}$ for the highest-emission $\mathrm{RCP}$ relative to pre-industrial levels (Meinshausen et al., 2011).

To estimate future aridity, five GCM runs for $E T_{\mathrm{o}}$ and the aridity index $(A I)$, where $A I$ is defined as a ratio of $E T_{\text {o }}$ to $P$, were produced for each of the four emission scenarios. For RCP2.6, RCP 4.5, RCP 6.0, and RCP 8.5, projected changes were assessed for a 30 -year period in the mid-21st century covering 2041-2070, relative to the baseline period of 1981-2010. AI anomalies, as the differences between the period of 2041-2070 and 1981-2010 averaged for the five future GCM-simulated climates, were computed for each grid. Models were assumed to be independent and given the same weight. The multi-model ensemble can be used to provide both a consensus representation of the climate system and some measure of how much confidence might be placed in that consensus (Taylor et al., 2012). P, ET $T_{\mathrm{o}}$, and $A I$ anomalies for China as a whole $(\Delta M)$ for each RCP were computed as follows:

$$
\Delta M_{s}=\frac{\sum_{i=1}^{n}\left(\left(M_{s, i, f}-M_{s, i, b s}\right) / M_{s, i, b s} \times 100 \times A_{i}\right)}{\sum_{i=1}^{n} A_{i}}
$$

where $s$ denotes the climate scenario, $i$ is the number of the grid (between 1 and 3997 for the study boundaries), $f$ denotes the period from 2014 to $2070, b s$ denotes the baseline period from 1981 to 2010, and $A_{i}$ is area of the $i$ th grid.

\subsection{Meteorological data and model performance matric}

To evaluate the behaviour of the five GCMs in simulating aridity over China, simulated present temperature (T), $P, E T_{\mathrm{o}}$, and $A I$ were compared with gauge-based observations and estimates. Observations of daily mean, maximum, and minimum air temperatures; mean relative humidity; sunshine duration; and mean wind speed at multiple sites over China were obtained from the National Meteorological Center of the China Meteorological Administration (CMA). Quality-controlled observations from 603 meteorological stations with less than 5\% missing data for the period 1981-2010 were compiled. Missing data were estimated by averaging values obtained from the same station during other years. To facilitate GCM validation, the annual gauge-based observations and estimates were interpolated onto a $0.5^{\circ} \times 0.5^{\circ}$ grid, identical to that of the ISI-MIP resolution, using the thin-spline plate approach.

We present an analysis of the model outputs in terms of the root-mean-square error (RMSE), correlation $(r)$, and standard deviation (SD). Values are presented in a Taylor diagram (Taylor, 2001), which summarizes these three values using a single point. Smaller RMSE values indicate more accurate model estimates. Correlation coefficients are used to describe the temporal and spatial similarity between the observation and the simulation. RMSE is given by:

$$
\mathrm{RMSE}=\sqrt{\frac{\sum_{i=1}^{n}\left[\left(y_{i}-\bar{y}\right)-\left(x_{i}-\bar{x}\right)\right]^{2}}{n}}
$$

where $x_{i}$ represents the $i$ th sample of a variable, $y_{i}$ is the corresponding climatology in the GCM simulation, and $n$ is the number of samples. To facilitate evaluations for different fields with different units, the RMSE and SD for each variable were normalized against the standard deviation of the corresponding observed field (Taylor, 2001).

\subsection{Reference evapotranspiration and aridity index}

Direct measurements of $E T_{\mathrm{o}}$ using methods such as eddy covariance, lysimeters, and the Bowen ratio method are generally localized and expensive, making estimates from meteorological variables desirable. Here $E T_{\mathrm{o}}$ is simulated by the Penman-Monteith model recommended by the Food and Agricultural Organization (hereafter the FAO56-PM model). The FAO56 reference crop evapotranspiration method (Allen et al., 1998) is recognized as the most effective and reliable method for estimating evapotranspiration, and is a simplified parameterization of the classical PM model for $E T_{\mathrm{o}}$ (van der Schrier et al., 2013). The FAO56-PM model is the most effective method for humid and arid conditions (Jensen et al., 1990), and has been found to provide a good reproduction of the spatial and seasonal variability of $E T_{\mathrm{o}}$ across Great Britain 
(Prudhomme and Williamson, 2013). In addition, McVicar et al. (2012) advocate that assessing evaporative demand trends requires consideration of all four primary meteorological variables; i.e. wind speed, atmospheric humidity, radiation, and air temperature. Thus, the physically based FAO56-PM method was used in this study to evaluate $E T_{\mathrm{o}}$. The model defines a hypothetical reference crop, $0.12 \mathrm{~m}$ high, without water stress, and integrates the mass transfer and energy balance by considering vegetation physiological functions (Allen et al., 1998). Daily $E T_{\mathrm{o}}$ is calculated as:

$$
E T_{\mathrm{o}}=\frac{0.408 \Delta\left(R_{n}-G\right)+\gamma \frac{900}{T+273} U_{2}\left(e_{s}-e_{a}\right)}{\Delta+\gamma\left(1+0.34 U_{2}\right)}
$$

where $R_{n}$ is net radiation $\left(\mathrm{MJ} \mathrm{m}^{-2} \mathrm{day}^{-1}\right), G$ is the soil heat flux $\left(\mathrm{MJ} \mathrm{m}^{-2} \mathrm{day}^{-1}\right), \gamma$ is the psychrometric constant $\left(\mathrm{kPa}{ }^{\circ} \mathrm{C}^{-1}\right), \Delta$ is the slope of the saturation vapour pressure curve $\left(\mathrm{kPa}^{\circ} \mathrm{C}^{-1}\right), T$ is air temperature $\left({ }^{\circ} \mathrm{C}\right), U_{2}$ is wind speed at a height of $2 \mathrm{~m}\left(\mathrm{~m} \mathrm{~s}^{-1}\right), e_{\mathrm{s}}$ is the mean saturation vapour pressure $(\mathrm{kPa})$ and $e_{\mathrm{a}}$ is the actual vapour pressure $(\mathrm{kPa})$, respectively. As the magnitude of the daytime soil-heat flux beneath the grass reference surface is relatively small, it can be ignored (Allen et al., 1998). Gauge-based $E T_{\mathrm{o}}$ is estimated based on the radiation-calibrated FAO56 Penman-Monteith model, which uses the calibrated Ångström solar radiation formula (Yin et al., 2008).

The $A I$, as the ratio between $E T_{\mathrm{o}}$ and $P$ (Budyko, 1974; Middleton and Thomas, 1992), is a widely used indicator of regional moisture conditions, and high values of the index indicate higher aridity.

\section{Results}

\subsection{Model evaluation}

The performance of the models in capturing the observed $T, P, E T_{0}$, and $A I$ was estimated before investigating changes in aridity over China. Figure 1 shows the time series of regionally averaged surface $T, P, E T_{\mathrm{o}}$, and $A I$ anomalies relative to baseline (1981-2010) conditions. These results were compared with observations over China between 1981 and 2010, and both series were smoothed using the 10-year running mean. Generally, observations over the historical period tend to be within the ensemble's one standard-deviation spread. For regionally averaged temporal changes, the models compare well with observed climate variables, except for $E T_{\mathrm{o}}$ and $A I$ in the 1990s when there is a positive bias. The bias is probably related to the observed decline of wind speed which has not been captured by the GCMs.

Changes in the four fields show considerable variation between models and scenarios. The fields have similar trends, but the magnitude of the changes varies between RCPs, particularly after 2030. Annual surface $T$ and $E T_{\text {o }}$ increase consistently in all models. Relative to the baseline period, annual $T$ rises by $1.81^{\circ} \mathrm{C}$ and $2.84^{\circ} \mathrm{C}$ by 2050 , and by $1.58^{\circ} \mathrm{C}$ and $6.50^{\circ} \mathrm{C}$ at the end of the $21^{\text {st }}$ century, for RCP2.6 and RCP8.5, respectively. Annual ET increases substantially, particularly for RCP 8.5 , which shows an increase of $10.35 \%$ by 2050 , and $24.22 \%$ at the end of the $21^{\text {st }}$ century. $P$ anomalies are projected to be negative between 2010 and 2020, after which they become positive for the remainder of the study period. The lowest increase in $P$ was for RCP6.0, which resulted in increases of $2.07 \%$ and $4.85 \%$ by 2050 and 2099 , respectively. At the end of the 21 st century, $P$ in China as a whole is likely to increase by about $10 \%$ (except for RCP6.0).

$A I$ anomalies are more heterogeneous than other variables with a low variance between models. After 2010, there are slight upward trends in $A I$ anomalies in RCP6.0 and RCP8.5. However, for RCP2.6 and RCP4.5, although positive anomalies do occur after 2010, there are no obvious trends in $A I$ (Figure 1). AI increases for RCP 8.5 are the most significant, with increases of $8.18 \%$ and $13.08 \%$ in 2050 and 2099, respectively (Table 2).
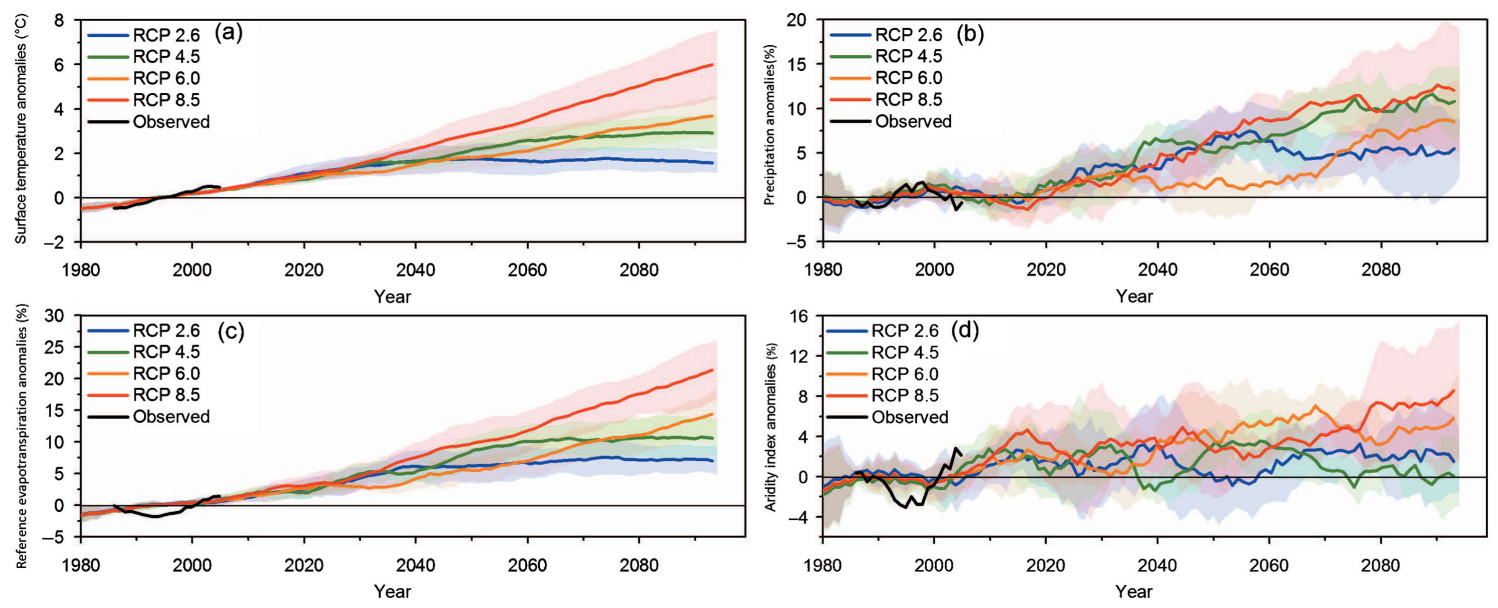

Figure 1. Modelled and observed regional spatial averages of (a) temperature change, (b) precipitation, (c) reference evapotranspiration, and (d) aridity index over China displayed as anomalies relative to 1981-2010. Solid lines indicate the five-GCM ensemble means under representative concentration pathway scenarios, and the shading indicates one standard deviation of the ensemble mean spread. The time series were smoothed using the 10-year running mean. 
Table 2. Changes in temperature, precipitation, reference evapotranspiration, and aridity index relative to the baseline period for four RCPs over China by 2050 and 2099.

\begin{tabular}{lccrrr}
\hline Variable & Year & RCP 2.6 & RCP 4.5 & RCP 6.0 & RCP 8.5 \\
\hline$T\left({ }^{\circ} \mathrm{C}\right)$ & 2050 & 1.81 & 2.18 & 1.52 & 2.84 \\
& 2099 & 1.58 & 2.94 & 3.78 & 6.50 \\
$P(\%)$ & 2050 & 5.73 & 3.50 & 2.07 & 2.15 \\
& 2099 & 9.00 & 10.33 & 4.85 & 10.17 \\
$E T_{\mathrm{o}}(\%)$ & 2050 & 6.60 & 9.27 & 4.05 & 10.35 \\
& 2099 & 6.36 & 10.53 & 15.89 & 24.22 \\
$A I(\%)$ & 2050 & 0.58 & 5.45 & 1.57 & 8.18 \\
& 2099 & -2.56 & -0.11 & 11.06 & 13.08 \\
\hline
\end{tabular}

Statistics are presented on a Taylor diagram in Figure 2, which shows the total spatial and temporal variability of the four evaluated fields. For surface air temperature, all five GCMs have a correlation with observations of $r>0.96$, for $P$ the correlation is approximately 0.80 , and for $E T_{\mathrm{o}}$ it is between 0.68 and 0.76 . The correlation is lower for $A I$ than for the other variables, with $r \approx 0.60$. The normalized standard deviation of space-time variations in $T$ is near 1, and for the other modelled variables, it is between 0.75 and 1.25. Nevertheless, all GCMs are generally capable of simulating the regional variability in aridity over China, but multi-model means have a higher correlation and lower RMSE than any individual GCM. Thus, the multi-model mean was used in the climate projections to reduce the errors and uncertainties associated with using an individual model.

The spatial distribution of observed and multi-model mean $E T_{\mathrm{o}}$ and $A I$ over China averaged for the three decades between 1981 and 2010 are presented in Figure 3. The results show lower $E T_{\mathrm{o}}$ primarily in northeast China and east of the Tibetan Plateau, and higher $E T_{\mathrm{o}}$ mainly in northwest China and southeast China. The model does show the spatial variability in $E T_{\mathrm{o}}$, but the magnitudes tend be higher than observations, especially in northwest and central China. Nevertheless, the simulated spatial distribution of $E T_{\mathrm{o}}$ is generally consistent with the observations, and has a spatial correlation coefficient of 0.77 .

For $A I$, there is a spatial transition from low $A I$ (humid) in southeast China to high $A I$ (arid) in northwest China. As shown in Figure 3(c) and (d), the simulations capture the southeast-northwest contrast and compare favourably with observations, with a spatial correlation coefficient of 0.76 . However, there is both a positive and negative bias in the simulated $A I$, with larger modelled magnitudes over southeast China, but smaller magnitudes mainly in northwest China, when compared with the observations.
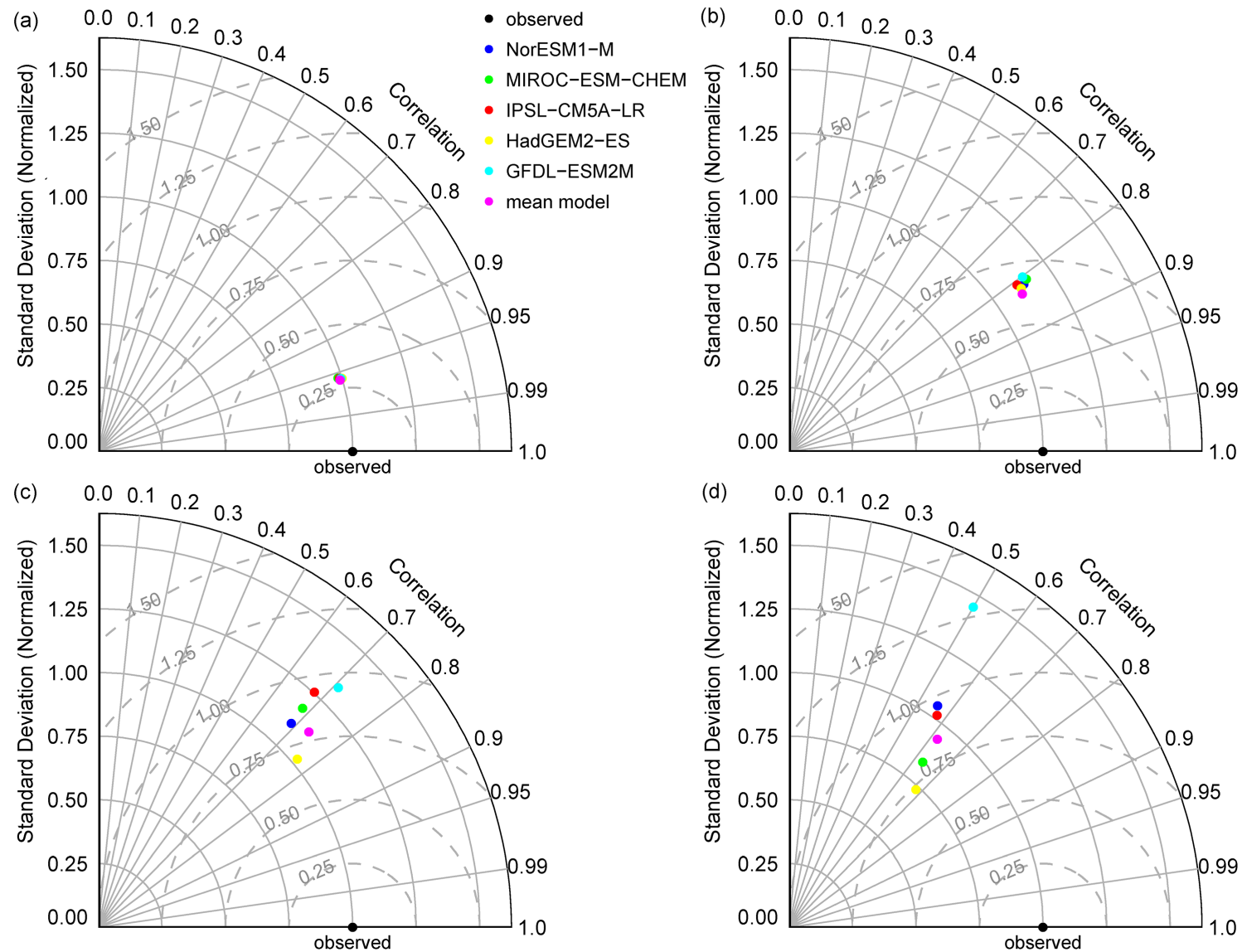

Figure 2. Taylor diagrams for projected (a) temperature change, (b) precipitation, (c) reference evapotranspiration, and (d) aridity index over China evaluated against observed fields for the 30-year period 1981-2010. The Taylor diagrams compare actual observations with GCM simulations, and summarize three metrics of the correlation (curved axis), the ratio of the standard deviations ( $x$ and $y$ axes), and the RMSE (dashed line). The closer a point is to the observed data, the better the fit between observed and simulated data. 

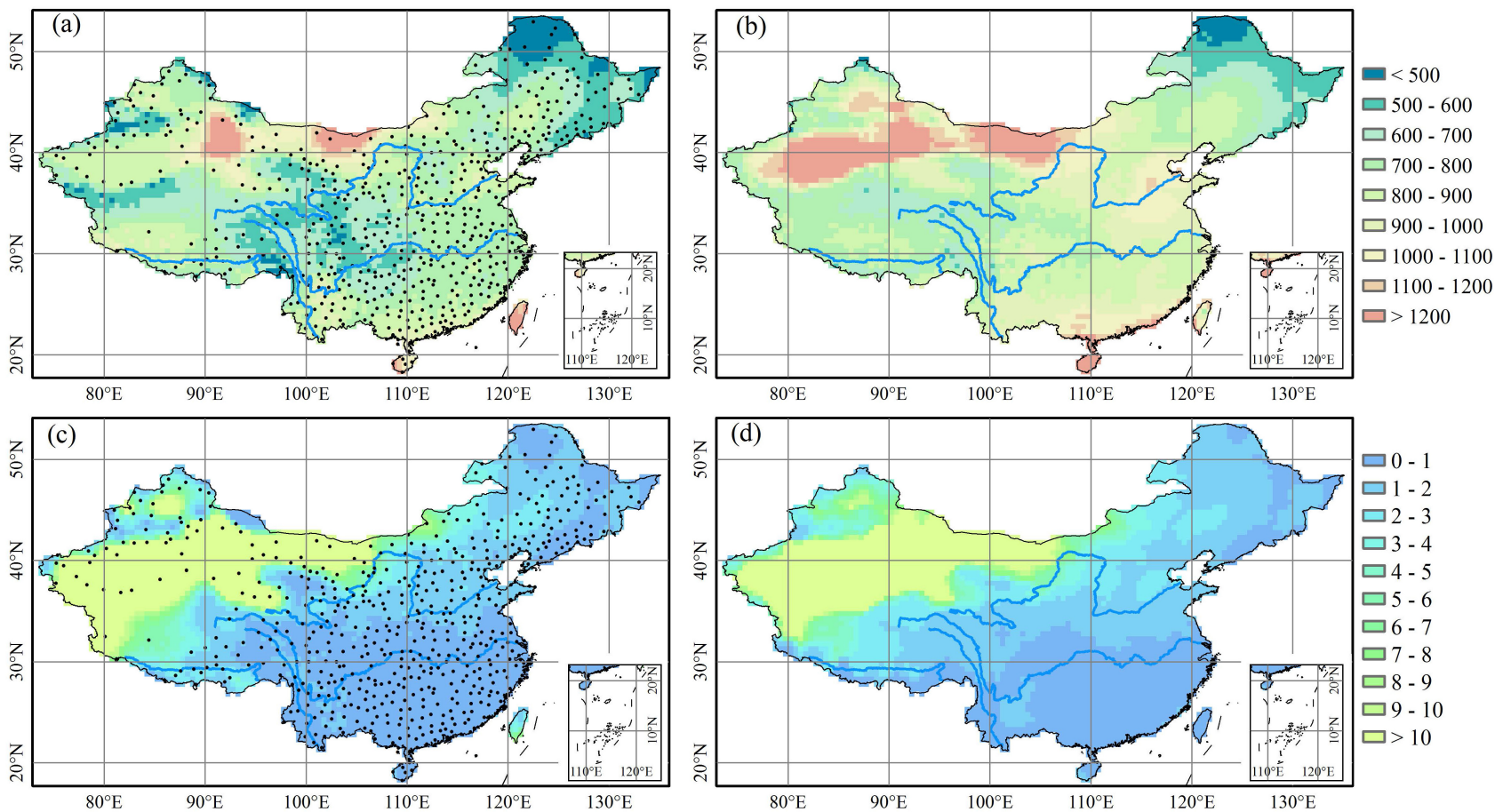

Figure 3. Observed (a, c) and simulated multi-model mean (b, d) reference evapotranspiration (a, b) and aridity index (c, d) over China from 1981 to 2010. Dark dots indicate the 603 meteorological stations used in the analysis (spatial correlations of $E T_{\text {o }}$ and $A I$ are 0.77 and 0.76 , respectively).

\subsection{Future changes in aridity over China}

Figure 4 show the projected ensemble-mean changes in $P$ for each RCP over China from the mid-21st century (2041-2070) to the present-day (1981-2010). Precipitation is projected to increase in the future over large areas of China relative to the baseline period. Spatial patterns shown in Figure 4 indicate that total annual $P$ will increase substantially, especially in parts of western China, which show increases of more than $20 \%$. This larger-scale pattern is very similar for RCP2.6, RCP4.5, and RCP8.5, with the largest positive anomalies for RCP8.5. The main negative $P$ anomalies are found over southeast China in RCP6.0. The mean $P$ anomalies over China in the mid-21st century are $7.94 \%, 8.09 \%, 4.62 \%$, and $10.15 \%$ for RCP2.6, RCP4.5, RCP6.0, and RCP8.5, respectively (Figure 5).

Figure 6 shows the spatial distribution of changes in simulated $E T_{\mathrm{o}}$ in the mid-21st century relative to the baseline period. Results show positive changes in annual $E T_{\mathrm{o}}$ for all four RCPs. Changes in $E T_{\mathrm{o}}$ for RCP8.5, with the highest greenhouse gas increase, have a larger magnitude than for other RCPs. For RCP8.5, annual $E T_{\text {o }}$ has a clear increase of more than $10 \%$ in northeast and southeast China, but a smaller increase of no more than $10 \%$ in regions west of $100^{\circ} \mathrm{E}$. The magnitude of modelled $E T_{\text {o }}$ is similar for RCP2.6 and RCP6.0, with positive anomalies of no more than $6 \%$ in western China, and between $6 \%$ and $10 \%$ for the majority of eastern China. As shown in Figure 5, the mean $E T_{\text {o }}$ anomalies over China in the mid-21st century are similar for RCP2.6 and RCP6.0, with means of around $7 \%$, but a little higher for RCP8.5 with a mean of $11.24 \%$. It is also of note that the range of $E T_{\mathrm{o}}$ anomalies is not much higher than that of $P$ and $A I$, and that all the values are positive.

Generally, negative $A I$ anomalies indicate increased humidity, while positive anomalies indicate severe aridity. Figure 7 shows the spatial patterns of percentage changes in annual $A I$ for the period 2041-2070 relative to 1981-2010. The large-scale patterns of annual AI are generally similar among the four RCPs. Anomalies in annual $A I$ are positive over the majority of China, with increases of $63.57 \%, 74.26 \%$, and $61.37 \%$ in RCP4.5, RCP6.0, and RCP8.5, respectively. The positive changes in $A I$ indicate a drying trend over most of China for all RCPs, except for RCP2.6, in which the negative and positive changes in $A I$ are nearly balanced. The increase in $P$ is likely to outweigh the increase in $E T_{\mathrm{o}}$ in most of western China, leading to negative changes in $A I$ and thus lessening the effects of increased aridity. The exception to this trend is northwest China, which is expected to have an increased $A I$. In contrast, for the majority of eastern China, $A I$ is projected to increase by approximately $10 \%$. Here, the positive changes in $A I$ are mainly due to a larger increase in $E T_{\text {o }}$ compared with $P$. Generally, the mean $A I$ change anomalies over China in the mid-21st century are relatively small $(<3 \%)$ except for RCP2.6, which has a slightly negative mean anomaly (Figure 5).

\section{Discussion}

To evaluate climate model performance in the baseline period, spatial and temporal variations from historical simulations were compared with observations. Validation of simulated aridity for 1981-2010 showed that the patterns 

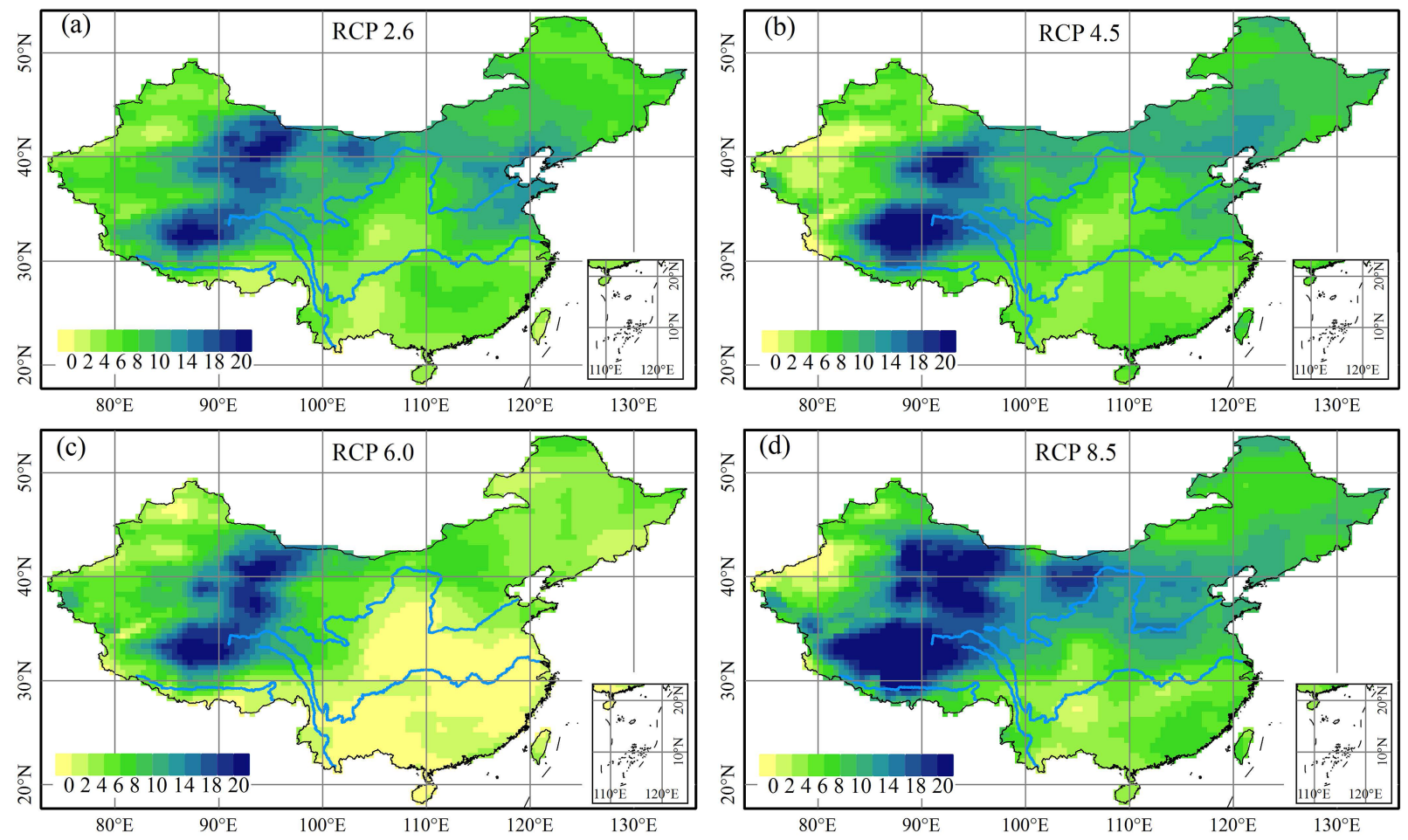

Figure 4. Percentage deviations in precipitation over China for the period 2041-2070 relative to 1981-2010 under (a) RCP2.6, (b) RCP4.5, (c) RCP6.0, and (d) RCP8.5, respectively.
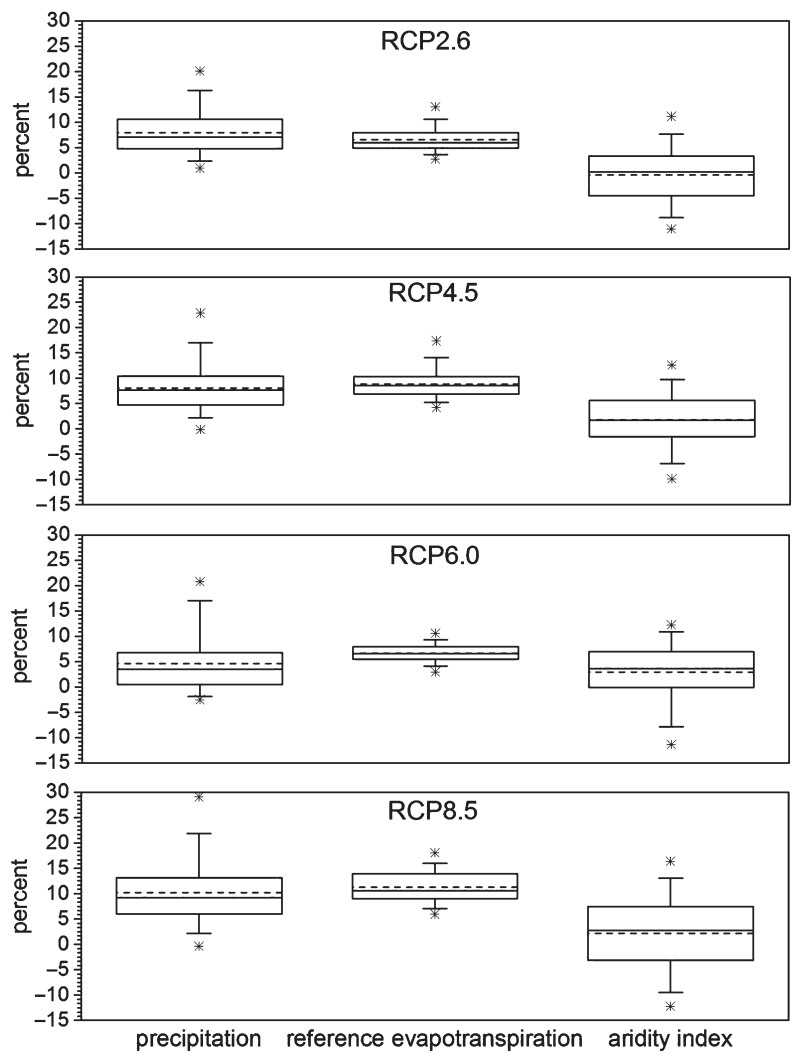

Figure 5. Predicted percentage changes in precipitation, reference evapotranspiration, and aridity index over China in the mid-21st century for each RCP. The median and mean values of the predicted changes are shown as solid and dashed lines inside the boxes; the box shows the 25 th-75th percentile range; whiskers extend to the 5th and 95th percentiles; and stars represent the 1st and 99th percentiles. of $E T_{\mathrm{o}}$ and the $A I$ were generally similar between models and observations over China. However, a number of uncertainties still remain. Higher uncertainties occur, especially in the Tibetan Plateau, where there is a sparse distribution of weather stations and complex topography (Figure 3). There may has a systematic bias over the Tibetan Plateau in the CMIP5 models (Su et al., 2012). Moreover, Inter-GCM variation in projected $P$ change is much larger than that of evapotranspiration change (Thompson et al., 2014). As indicated by Endo et al. (2012), uncertainties in future $P$ simulations in South and Southeast Asia are derived mainly from differences in cumulus schemes.

Projected evapotranspiration is a crucial challenge facing the assessment of climate change impact since uncertainty exists in estimated $E T_{\text {o }}$ (Prudhomme and Williamson, 2013). Uncertainty in $E T_{\text {o }}$ mainly arises from GCMs and various $E T_{\mathrm{o}}$ methods. For certain regions and GCMs, $E T_{\mathrm{o}}$ method can determine the direction of projections of future water resources, and further adds substantial uncertainty to the existing uncertainty associated with the climate change signal between GCMs (Kingston et al., 2009). McAfee (2013) suggested to use data-intensive methods to estimate changes in evaporative demand because the source(s) of uncertainty can be identified (McAfee, 2013). Even so, the $E T_{\text {o }}$ method-related uncertainty is much less than the GCM-related uncertainty as for runoff projection (Kay and Davies, 2008; Thompson et al., 2014).

To reduce uncertainty in GCMs performance, an ensemble average of GCMs was used in this study. However, this does not provide a systematic assessment of true GCM structural uncertainty, an alternative is to apply GCM perturbed physics ensembles (Gosling et al., 2012), 

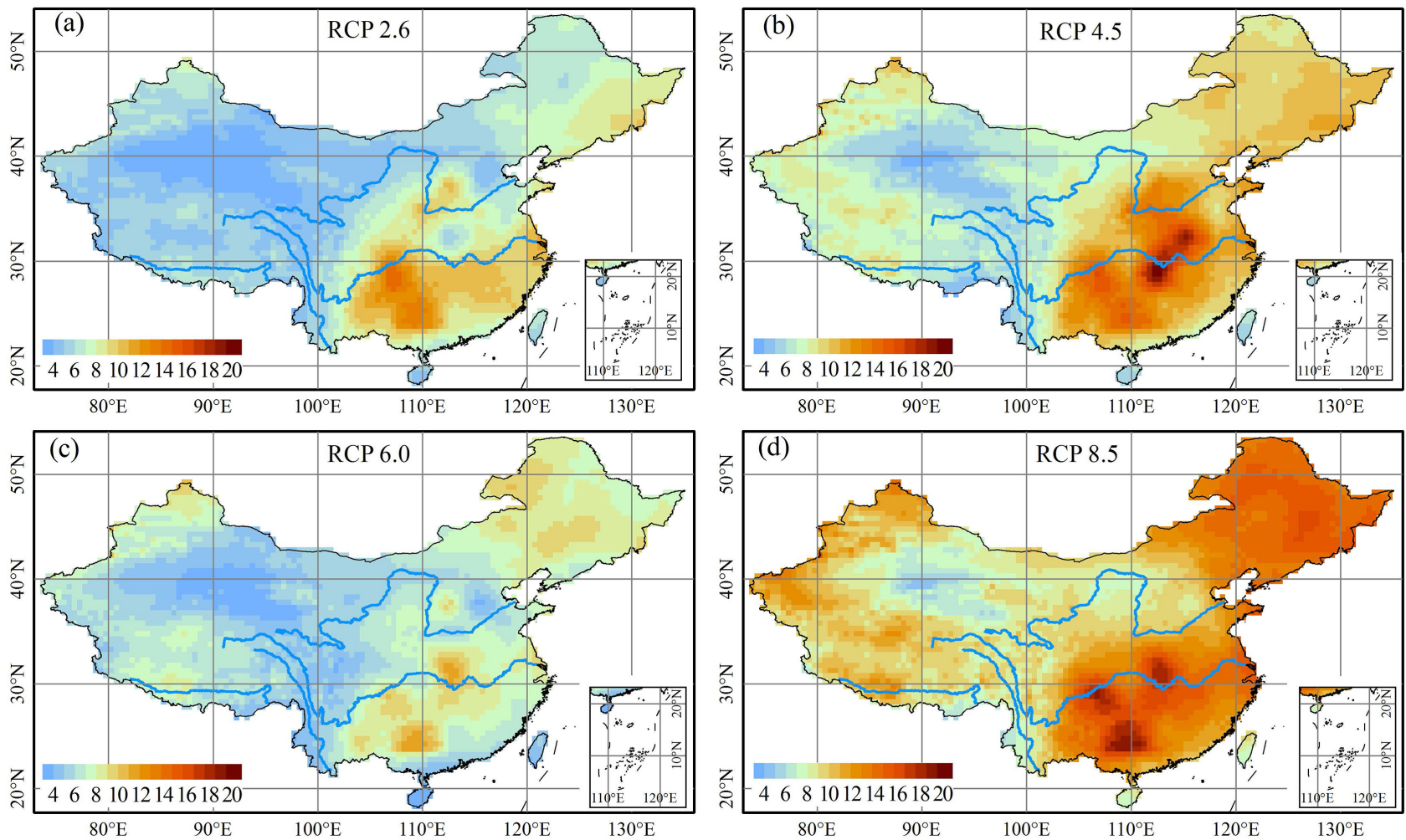

Figure 6. Percentage deviations in reference evapotranspiration over China during the period 2041-2070 relative to 1981-2010 under (a) RCP2.6, (b) RCP4.5, (c) RCP6.0, and (d) RCP8.5, respectively.

or a Bayesian model averaging method to reduce the GCM-ensemble uncertainty (Tebaldi and Knutti, 2007; Wang and Chen, 2014). For example, the multi-model ensemble bias in future $E T_{\text {o }}$ prediction of in the Haihe River Basin of China (Xing et al., 2014) and future precipitation prediction at regional scales (Tebaldi et al., 2004) has been reduced based on the Bayesian approach. Moreover, uncertainty in GCMs to simulate variability and trend in $P$ and $E T_{\text {o }}$ can be reduced by exclusion of the poorer GCMs according to their skill score and a certain threshold (Kirono and Kent, 2011). Generally, although climate models in CMIP5 capture most of the climatic processes, uncertainties in climate change are unlikely to decrease quickly, and the impact-relevant predictions may be even harder to improve (Knutti and Sedlacek, 2013). Further efforts should be made to deal with uncertainties in the impact of climate change, for example to constrain the sea surface temperature (SST) response pattern and the soil-moisture feedback in global climate scenarios (Joetzjer et al., 2013).

For temporal variations in the baseline period, simulated $E T_{\mathrm{o}}$ and $A I$ have a positive bias in the 1990 s, which results in a lower correlation and higher RMSE compared with $T$ and $P$. The discrepancy is probably related to wind speed simulations. As indicated by Chen et al. (2012), a positive bias exists in mean near-surface wind speeds over China, and hence none of the models reproduce the recent decline in wind speed that is manifest in near-surface observations. During the last several decades, annual $E T_{\mathrm{o}}$ has decreased in most regions worldwide, and this has been mainly attributed to declining wind speeds (Yin et al., 2010; McVicar et al., 2012). Decreased wind speed is usually associated with changes in the strength of large-scale changes in atmospheric circulation (Chen et al., 2006; Rayner, 2007). Despite the bias, GCM ensemble means are able to reproduce the general temporal and spatial variations of aridity over China between 1981 and 2010.

The projected increment of $P$ in China based on the latest GCMs from CMIP5 generally confirms the findings from previous studies. For example, Gu et al. (2012) applied a regional climate model (RegCM4) and found positive changes in annual precipitation over most of China north of $30^{\circ} \mathrm{N}$ and negative or little change in the rest of China in 2070-2099. Recently, based on CMIP5 climate models, precipitation was generally projected to increase in China by the end of the 21 st century (Wang and Chen, 2014). Moreover, the most significant increases were projected to occur over the Tibetan Plateau and East China in summer, indicating the change in monsoonal circulation in the future (Chen and Frauenfeld, 2014). Precipitation is the main source of increased moisture, and $E T_{0}$, as a main source of atmospheric water demand, also plays an important role in the hydrologic budget. Therefore, although future annual mean total $P$ is projected to increase over most of China, it is likely to become drier over most of eastern China due to enhanced atmospheric water demand as greenhouse gas concentrations increase.

The positive changes in annual $E T_{\text {o }}$ projected in this study in response to future warming are comparable with previous results at both global scale (Kingston et al., 2009; 

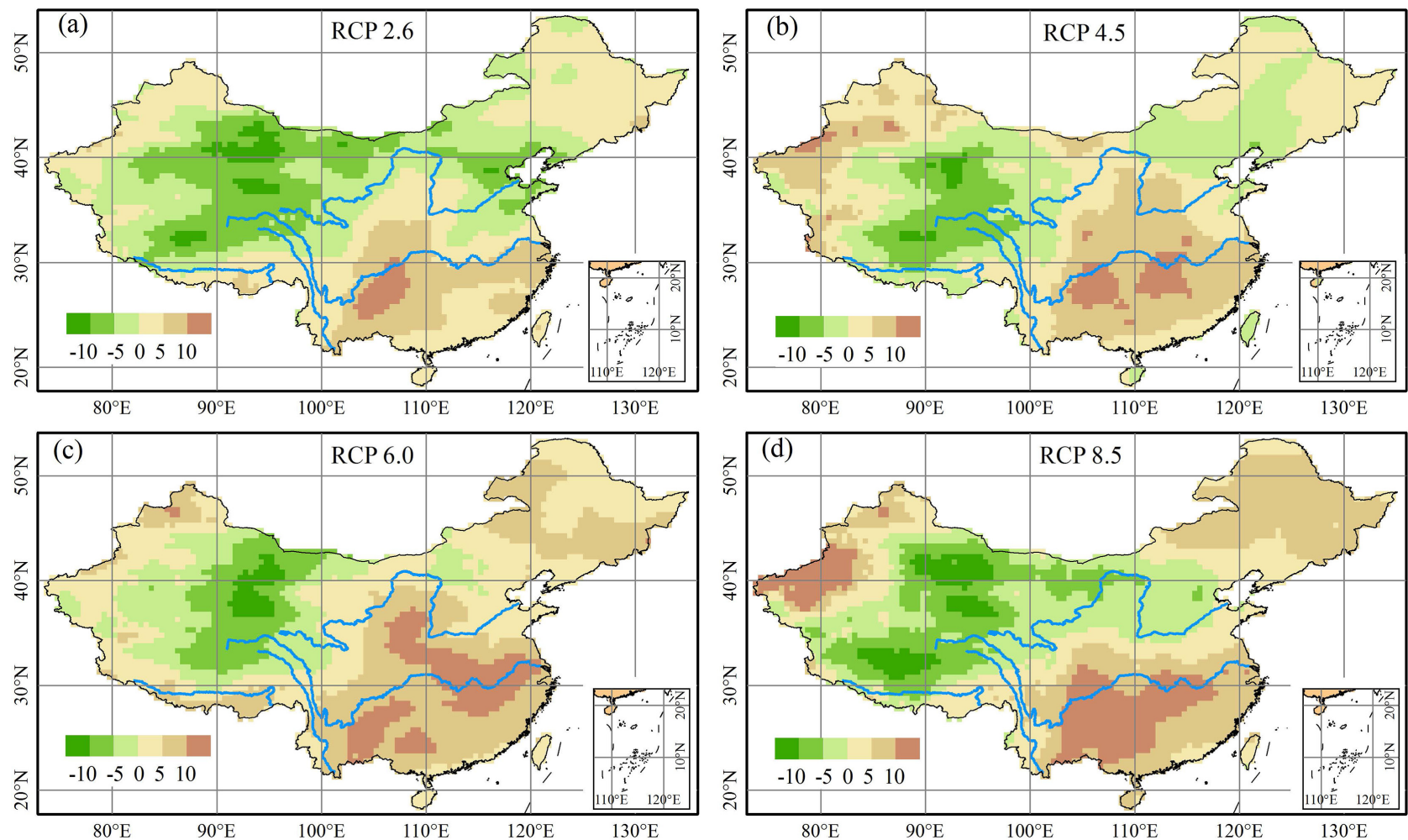

Figure 7. Percentage deviations in aridity index over China for the period 2041-2070 relative to 1981-2010 under (a) RCP2.6, (b) RCP4.5, (c) RCP6.0, and (d) RCP8.5, respectively.

Scheff and Frierson, 2013) and regions in China, such as the Tibetan Plateau (Wang et al., 2013), the Haihe River Basin (Xing et al., 2014), and the Zhejiang Province (Xu et al., 2014). The main reason for the projected increase in global $E T_{\mathrm{o}}$ is increased temperature, which increases the vapour pressure deficit and increases the Clausius-Clapeyron slope (Scheff and Frierson, 2013).

Projected changes in evapotranspiration demand and aridity provides profound implications that may be useful for future water resource management, agriculture and ecosystem structure and function. Our simulation of future aridity changes indicates that most of semiarid and arid regions in western China will experience less aridity, which may induce more available water and benefit to local ecosystem. However, there will not be possible to devoid water scarcity situation in the 21 st century because higher water demand than supply typically occurs. Meanwhile, increased evapotranspiration and aridity were projected across most of eastern China in the mid-21st century. Enhancement $E T_{\mathrm{o}}$ may have negative implications on ecosystem and agriculture, like crop growth in the Haihe River Basin which is an important grain production base in eastern China (Wang et al., 2011). Moreover, increased aridity has the potential impact on grassland composition and productivity (Clark et al., 2002), and the forest growth would decline and mortality rates may increase substantially response to rising aridity (Williams et al., 2010). Therefore, ecosystem across the eastern China would be affected adversely by future warming and increasing aridity.
At global or regional scales, $A I$ is conventionally used to classify the land surface into different moisture regimes such as arid, semi-arid, sub-humid, and humid zones, corresponding to the following types of natural potential vegetation: forest, forest steppe including meadow, steppe, and desert, respectively (Zheng, 1999; Zheng et al., 2013). The spatial differences in $A I$ changes may result in the migration of arid or humid regimes, and transfer ecosystem patterns as well. For example, the substantially decreased projected $A I$ in western China would probably lead to a reduction in the arid zone, and increased $A I$ in eastern China would lead to a reduction in the humid zone. Further analysis will be necessary if we are to evaluate the potential impacts of future aridity changes and the migration of moisture regimes.

\section{Summary and conclusions}

This paper aims to provide an overview of aridity changes projected for the mid-21st century relative to the 1981-2010 baseline conditions. Future projections of changing aridity using five GCMs that participated in the ISI-MIP over China were analyzed for four RCPs, after evaluating the performances of the GCMs against observations from 603 meteorological stations. The FAO56 Penman-Monteith model was used to simulate $E T_{\text {o }}$ and the corresponding aridity over China.

GCM ensemble-means reproduced the general temporal and spatial variations of aridity during the baseline period over China. A positive $E T_{\mathrm{o}}$ bias was found mainly in 
northwest and central China. Simulated annual $A I$ had a positive bias over southeast China and a negative bias mainly in northwest China.

In the mid-21st century, modelled $E T_{\mathrm{o}}$ anomalies are consistently positive for all four RCPs over China, especially in the southeast and northeast, which show positive changes of more than $10 \%$. In contrast to the $E T_{\mathrm{o}}$ trends, which are spatially homogeneous, annual $P$ anomalies show little spatial consistency. Precipitation is generally projected to increase over China in the mid-21st century relative to the baseline period. Regions with significantly increased $P$ are mainly concentrated in western China. RCP8.5, which has the highest greenhouse gas increase, results in higher-magnitude anomalies than the three other RCPs for both $P$ and $E T_{\mathrm{o}}$. There are also large differences between modelled anomalies in each RCP, particularly after 2030. For most areas in eastern China, $A I$ is projected to increase, while for most of western China $A I$ is projected to decrease between 1981-2010 and 2041-2070.

In general, future aridity changes are projected to show strong contrasts from west (decreased aridity) to east (increased aridity). Wide areas of eastern China are likely to face an increased risk of drought, despite positive $P$ anomalies, due to the much more substantial effects of climate change on atmospheric moisture demand $\left(E T_{\mathrm{o}}\right)$. However, the projected increase in $P$ generally outweighs that in atmospheric moisture demand, and this should lead to higher humidity across the majority of western China in the $21^{\text {st }}$ century.

\section{Acknowledgements}

This study was supported by the National Science and Technology Support Program (grants 2012BAC19B02), and also the 'Strategic Pilot Science and Technology Program' of Chinese Academy of Sciences (grants XDA05090304). The authors thank the ISI-MIP for providing us with bias corrected climate data. We acknowledge the World Climate Research Programme's Working Group on Coupled Modeling, which is responsible for CMIP, and we thank the climate modelling groups (GFDL-ESM2M, HadGEM2-ES, IPSL-CM5A-LR, MIROC-ESM-CHEM, and NorESM1-M) for producing and making available their model output.

\section{References}

Allen RG, Pereira LS, Raes D, Smith M. 1998. Crop EvapotranspirationGuidelines for Computing Crop Water Requirements-FAO Irrigation and Drainage Paper 56. FAO: Rome.

Arora VK. 2002. The use of the aridity index to assess climate change effect on annual runoff. J. Hydrol. 265(1-4): 164-177, doi: 10.1016/s0022-1694(02)00101-4.

Bentsen M, Bethke I, Debernard JB, Iversen T, Kirkevåg A, Seland $\varnothing$, Drange H, Roelandt C, Seierstad IA, Hoose C, Kristjánsson JE. 2013. The Norwegian Earth System Model, NorESM1-M - Part 1: description and basic evaluation of the physical climate. Geosci. Model Dev. 6(3): 687-720, doi: 10.5194/gmd-6-687-2013.

Budyko MI. 1974. Climate and Life. Academic Press: New York, NY.

Chen L, Frauenfeld OW. 2014. A comprehensive evaluation of precipitation simulations over China based on CMIP5 multimodel ensemble projections. J. Geophys. Res. Atmos. 119(10): 5767-5786, doi: 10.1002/2013JD021190.

Chen S, Liu Y, Thomas A. 2006. Climatic change on the Tibetan Plateau: potential evapotranspiration trend from 1961-2006. Clim. Change 76: 291-319, doi: 10.1007/s10584-006-9080-z.

Chen L, Pryor SC, Li DL. 2012. Assessing the performance of Intergovernmental Panel on Climate Change AR5 climate models in simulating and projecting wind speeds over China. J. Geophys. Res. Atmos. 117(D24): D24102, doi: 10.1029/2012jd017533.

Clark JS, Grimm EC, Donovan JJ, Fritz SC, Engstrom DR, Almendinger JE. 2002. Drought cycles and landscape responses to past aridity on prairies of the northern Great Plains, USA. Ecology 83(3): 595-601, doi: $10.2307 / 3071864$.

Collins WJ, Bellouin N, Doutriaux-Boucher M, Gedney N, Halloran $\mathrm{P}$, Hinton T, Hughes J, Jones CD, Joshi M, Liddicoat S, Martin G, O'Connor F, Rae J, Senior C, Sitch S, Totterdell I, Wiltshire A, Woodward S. 2011. Development and evaluation of an Earth-System model - HadGEM2. Geosci. Model Dev. 4(4): 1051-1075, doi: 10.5194/gmd-4-1051-2011.

Dai AG. 2011. Drought under global warming: a review. WIREs Clim. Change 2(1): 45-65, doi: 10.1002/wcc.81.

Dai AG. 2013. Increasing drought under global warming in observations and models. Nat. Clim. Change 3(1): 52-58, doi: 10.1038/nclimate 1633.

Davie JCS, Falloon PD, Kahana R, Dankers R, Betts R, Portmann FT, Wisser D, Clark DB, Ito A, Masaki Y, Nishina K, Fekete B, Tessler Z, Wada Y, Liu X, Tang Q, Hagemann S, Stacke T, Pavlick R, Schaphoff S, Gosling SN, Franssen W, Arnell N. 2013. Comparing projections of future changes in runoff from hydrological and biome models in ISI-MIP. Earth Syst. Dynam. 4(2): 359-374, doi: 10.5194/esd-4-359-2013.

Delgado-Baquerizo M, Maestre FT, Gallardo A, Bowker MA, Wallenstein MD, Quero JL, Ochoa V, Gozalo B, Garcia-Gomez M, Soliveres S, Garcia-Palacios P, Berdugo M, Valencia E, Escolar C, Arredondo T, Barraza-Zepeda C, Bran D, Carreira JA, Chaieb M, Conceicao AA, Derak M, Eldridge DJ, Escudero A, Espinosa CI, Gaitan J, Gatica MG, Gomez-Gonzalez S, Guzman E, Gutierrez JR, Florentino A, Hepper E, Hernandez RM, Huber-Sannwald E, Jankju M, Liu J, Mau RL, Miriti M, Monerris J, Naseri K, Noumi Z, Polo V, Prina A, Pucheta E, Ramirez E, Ramirez-Collantes DA, Romao R, Tighe M, Torres D, Torres-Diaz C, Ungar ED, Val J, Wamiti W, Wang D, Zaady E. 2013. Decoupling of soil nutrient cycles as a function of aridity in global drylands. Nature 502(7473): 672-676, doi: 10.1038/nature12670.

Dolman AJ, de Jeu RAM. 2010. Evaporation in focus. Nat. Geosci. 3(5): 296, doi: 10.1038/ngeo849.

Dufresne JL, Foujols MA, Denvil S, Caubel A, Marti O, Aumont O, Balkanski Y, Bekki S, Bellenger H, Benshila R, Bony S, Bopp L, Braconnot P, Brockmann P, Cadule P, Cheruy F, Codron F, Cozic A, Cugnet D, de Noblet N, Duvel JP, Ethé C, Fairhead L, Fichefet T, Flavoni S, Friedlingstein P, Grandpeix JY, Guez L, Guilyardi E, Hauglustaine D, Hourdin F, Idelkadi A, Ghattas J, Joussaume S, Kageyama M, Krinner G, Labetoulle S, Lahellec A, Lefebvre MP, Lefevre F, Levy C, Li ZX, Lloyd J, Lott F, Madec G, Mancip M, Marchand M, Masson S, Meurdesoif Y, Mignot J, Musat I, Parouty S, Polcher J, Rio C, Schulz M, Swingedouw D, Szopa S, Talandier C, Terray P, Viovy N, Vuichard N. 2013. Climate change projections using the IPSL-CM5 Earth System Model: from CMIP3 to CMIP5. Clim. Dynam. 40(9-10): 2123-2165, doi: 10.1007/s00382-0121636-1.

Dunne JP, John JG, Adcroft AJ, Griffies SM, Hallberg RW, Shevliakova E, Stouffer RJ, Cooke W, Dunne KA, Harrison MJ, Krasting JP, Malyshev SL, Milly PCD, Phillipps PJ, Sentman LT, Samuels BL, Spelman MJ, Winton M, Wittenberg AT, Zadeh N. 2012. GFDL's ESM2 global coupled climate-carbon earth system models. Part I: physical formulation and baseline simulation characteristics. J. Clim. 25(19): 6646-6665, doi: 10.1175/Jcli-D-11-00560.1.

Eitzinger J, Trnka M, Semeradova D, Thaler S, Svobodova E, Hlavinka P, Siska B, Takac J, Malatinska L, Novakova M, Dubrovsky M, Zalud Z. 2013. Regional climate change impacts on agricultural crop production in Central and Eastern Europe - hotspots, regional differences and common trends. J. Agr. Sci. 151(6): 787-812, doi: $10.1017 /$ S0021859612000767.

Endo H, Kitoh A, Ose T, Mizuta R, Kusunoki S. 2012. Future changes and uncertainties in Asian precipitation simulated by multiphysics and multi-sea surface temperature ensemble experiments with high-resolution Meteorological Research Institute atmospheric general circulation models (MRI-AGCMs). J. Geophys. Res. 117(D16): D16118, doi: 10.1029/2012jd017874. 
Feng S, Fu Q. 2013. Expansion of global drylands under a warming climate. Atmos. Chem. Phys. 13(19): 10081-10094, doi: 10.5194/acp-13-10081-2013.

Gao X, Giorgi F. 2008. Increased aridity in the Mediterranean region under greenhouse gas forcing estimated from high resolution simulations with a regional climate model. Global Planet Change 62(3-4): 195-209, doi: 10.1016/j.gloplacha.2008.02.002.

Golubev VS, Lawrimore JH, Groisman PY, Speranskaya NA, Zhuravin SA, Menne MJ, Peterson TC, Malone RW. 2001. Evaporation changes over the contiguous United States and the former USSR: a reassessment. Geophys. Res. Lett. 28(13): 2665-2668, doi: 10.1029/2000GL012851.

Gosling SN, McGregor GR, Lowe JA. 2012. The benefits of quantifying climate model uncertainty in climate change impacts assessment: an example with heat-related mortality change estimates. Clim. Change 112(2): 217-231, doi: 10.1007/s10584-011-0211-9.

$\mathrm{Gu} \mathrm{HH}$, Wang GL, Yu ZB, Mei R. 2012. Assessing future climate changes and extreme indicators in east and south Asia using the RegCM4 regional climate model. Clim. Change 114(2): 301-317, doi: 10.1007/s10584-012-0411-y.

Held IM, Soden BJ. 2006. Robust responses of the hydrological cycle to global warming. J. Clim. 19(21): 5686-5699, doi: 10.1175/JCLI3990.1.

Hempel S, Frieler K, Warszawski L, Schewe J, Piontek F. 2013. A trend-preserving bias correction - the ISI-MIP approach. Earth Syst. Dynam. 4(2): 219-236, doi: 10.5194/esd-4-219-2013.

IPCC. 2013. Summary for Policymakers. In Working Group I Contribution to the IPCC Fifth Assessment Report Climate Change 2013: The Physical Science Basis. Cambridge University Press: Cambridge, UK

Izaurralde RC, Rosenberg NJ, Brown RA, Thomson AM. 2003. Integrated assessment of Hadley Center (HadCM2) climate-change impacts on agricultural productivity and irrigation water supply in the conterminous United States - Part II. Regional agricultural production in 2030 and 2095. Agr. Forest. Meteorol. 117(1-2) 97-122, doi: 10.1016/S0168-1923(03)00024-8.

Jensen ME, Burman RD, Allen RG. 1990. Evapotranspiration and Irrigation Requirements. ASCE Manuals and Reports on Engineering Practice No. 70. American Society of Civil Engineer: New York, NY.

Joetzjer E, Douville H, Delire C, Ciais P. 2013. Present-day and future Amazonian precipitation in global climate models: CMIP5 versus CMIP3. Clim. Dynam. 41(11-12): 2921-2936, doi: 10.1007/s00382-012-1644-1.

Kay AL, Davies HN. 2008. Calculating potential evaporation from climate model data: a source of uncertainty for hydrological climate change impacts. J. Hydrol. 358(3-4): 221-239, doi: 10.1016/j.jhydrol.2008.06.005.

Kingston DG, Todd MC, Taylor RG, Thompson JR, Arnell NW. 2009. Uncertainty in the estimation of potential evapotranspiration under climate change. Geophys. Res. Lett. 36(20): L20403, doi: 10.1029/2009GL040267.

Kirono DGC, Kent DM. 2011. Assessment of rainfall and potential evaporation from global climate models and its implications for Australian regional drought projection. Int. J. Climatol. 31(9): 1295-1308, doi: $10.1002 /$ Joc. 2165.

Knutti R, Sedlacek J. 2013. Robustness and uncertainties in the new CMIP5 climate model projections. Nat. Clim. Change 3(4): 369-373, doi: 10.1038/Nclimate1716.

Liu B, Xu M, Henderson M, Gong W. 2004. A spatial analysis of pan evaporation trends in China, 1955-2000. J. Geophys. Res. Atmos. 109(D15): D15102, doi: 10.1029/2004JD004511.

McAfee SA. 2013. Methodological differences in projected potential evapotranspiration. Clim. Change 120(4): 915-930, doi: 10.1007/s10584-013-0864-7.

McCabe GJ, Wolock DM. 2002. Trends and temperature sensitivity of moisture conditions in the conterminous United States. Clim. Res. 20(1): 19-29, doi: 10.3354/cr020019.

McVicar TR, Roderick ML, Donohue RJ, Li LT, Van Niel TG, Thomas A, Grieser J, Jhajharia D, Himri Y, Mahowald NM, Mescherskaya AV, Kruger AC, Rehman S, Dinpashoh Y. 2012. Global review and synthesis of trends in observed terrestrial near-surface wind speeds: Implications for evaporation. J. Hydrol. 416: 182-205, doi 10.1016/j.jhydrol.2011.10.024.

Meinshausen M, Smith SJ, Calvin K, Daniel JS, Kainuma MLT, Lamarque JF, Matsumoto K, Montzka SA, Raper SCB, Riahi K, Thomson A, Velders GJM, Vuuren DPP. 2011. The RCP greenhouse gas concentrations and their extensions from 1765 to 2300. Clim. Change 109(1-2): 213-241, doi: 10.1007/s10584-011-0156-z.

Middleton N, Thomas DSG. 1992. World Atlas of Desertification. Edward Arnold: London.
Moss RH, Edmonds JA, Hibbard KA, Manning MR, Rose SK, van Vuuren DP, Carter TR, Emori S, Kainuma M, Kram T, Meehl GA, Mitchell JFB, Nakicenovic N, Riahi K, Smith SJ, Stouffer RJ, Thomson AM, Weyant JP, Wilbanks TJ. 2010. The next generation of scenarios for climate change research and assessment. Nature 463(7282): 747-756, doi: 10.1038/Nature08823.

Nastos PT, Politi N, Kapsomenakis J. 2013. Spatial and temporal variability of the Aridity Index in Greece. Atmos. Res. 119: 140-152, doi: 10.1016/j.atmosres.2011.06.017.

Peterson TC, Golubev VS, Groisman PY. 1995. Evaporation losing its strength. Nature 377(6551): 687-688, doi: 10.1038/377687b0.

Prudhomme C, Williamson J. 2013. Derivation of RCM-driven potential evapotranspiration for hydrological climate change impact analysis in Great Britain: a comparison of methods and associated uncertainty in future projections. Hydrol. Earth Syst. Sci. 17(4): 1365-1377, doi: 10.5194/hess-17-1365-2013.

Rayner DP. 2007. Wind run changes: the dominant factor affecting pan evaporation trends in Australia. J. Clim. 20(14): 3379-3394, doi: 10.1175/Jcli4181.1.

Roderick ML, Farquhar GD. 2002. The cause of decreased pan evaporation over the past 50 years. Science 298(5597): 1410-1411, doi: 10.1126/science.1075390.

Roderick ML, Sun F, Lim WH, Farquhar GD. 2014. A general framework for understanding the response of the water cycle to global warming over land and ocean. Hydrol. Earth Syst. Sci. 18(5): 1575-1589, doi: 10.5194/hess-18-1575-2014.

Scheff J, Frierson DMW. 2013. Scaling potential evapotranspiration with greenhouse warming. J. Clim. 27(4): 1539-1558, doi: 10.1175/JCLI-D-13-00233.1.

Schewe J, Heinke J, Gerten D, Haddeland I, Arnell NW, Clark DB, Dankers R, Eisner S, Fekete BM, Colon-Gonzalez FJ, Gosling SN, Kim H, Liu X, Masaki Y, Portmann FT, Satoh Y, Stacke T, Tang Q, Wada Y, Wisser D, Albrecht T, Frieler K, Piontek F, Warszawski L, Kabat P. 2014. Multimodel assessment of water scarcity under climate change. Proc. Natl. Acad. Sci. U. S. A. 111(9): 3245-3250, doi: 10.1073/pnas.1222460110.

van der Schrier G, Barichivich J, Briffa KR, Jones PD. 2013. A scPDSI-based global data set of dry and wet spells for 1901-2009. J. Geophys. Res. Atmos. 118(10): 4025-4048, doi: 10.1002/jgrd.50355. Sherwood S, Fu Q. 2014. A drier future? Science 343(6172): 737-739, doi: $10.1126 /$ science. 1247620.

Shi YF, Shen YP, Kang E, Li DL, Ding YJ, Zhang GW, Hu RJ. 2007. Recent and future climate change in northwest china. Clim. Change 80(3-4): 379-393, doi: 10.1007/s10584-006-9121-7.

Su F, Duan X, Chen D, Hao Z, Cuo L. 2012. Evaluation of the global climate models in the CMIP5 over the Tibetan Plateau. J. Clim. 26(10): 3187-3208, doi: 10.1175/JCLI-D-12-00321.1.

Taylor KE. 2001. Summarizing multiple aspects of model performance in a single diagram. J. Geophys. Res. Atmos. 106(D7): 7183-7192, doi: 10.1029/2000jd900719.

Taylor KE, Stouffer RJ, Meehl GA. 2012. An overview of CMIP5 and the experiment design. Bull. Am. Meteorol. Soc. 93(4): 485-498, doi: 10.1175/Bams-D-11-00094.1.

Tebaldi C, Knutti R. 2007. The use of the multi-model ensemble in probabilistic climate projections. Phil. Trans. R. Soc. A 365(1857): 2053-2075, doi: 10.1098/rsta.2007.2076.

Tebaldi C, Mearns LO, Nychka D, Smith RL. 2004. Regional probabilities of precipitation change: a Bayesian analysis of multimodel simulations. Geophys. Res. Lett. 31(24): L24213, doi: 10.1029/2004GL021276.

Thompson JR, Green AJ, Kingston DG. 2014. Potential evapotranspiration-related uncertainty in climate change impacts on river flow: an assessment for the Mekong River basin. J. Hydrol. 510: 259-279, doi: 10.1016/j.jhydrol.2013.12.010.

Wang L, Chen W. 2014. A CMIP5 multimodel projection of future temperature, precipitation, and climatological drought in China. Int. J. Climatol. 34(6): 2059-2078, doi: 10.1002/joc.3822.

Wang WG, Peng SZ, Yang T, Shao QX, Xu JZ, Xing WQ. 2011. Spatial and Temporal Characteristics of Reference Evapotranspiration Trends in the Haihe River Basin, China. J. Hydrol. Eng. 16(3): 239-252, doi: 10.1061/(ASCE)HE.1943-5584.0000320.

Wang WG, Xing WQ, Shao QX, Yu ZB, Peng SZ, Yang T, Yong B, Taylor J, Singh VP. 2013. Changes in reference evapotranspiration across the Tibetan Plateau: observations and future projections based on statistical downscaling. J. Geophys. Res. Atmos. 118(10): 4049-4068, doi: $10.1002 /$ jgrd.50393.

Warszawski L, Frieler K, Huber V, Piontek F, Serdeczny O, Schewe J. 2014. The Inter-Sectoral Impact Model Intercomparison Project 
(ISI-MIP): project framework. Proc. Natl. Acad. Sci. U. S. A. 111(9): 3228-3232, doi: 10.1073/pnas.1312330110.

Watanabe S, Hajima T, Sudo K, Nagashima T, Takemura T, Okajima H, Nozawa T, Kawase H, Abe M, Yokohata T, Ise T, Sato H, Kato E, Takata K, Emori S, Kawamiya M. 2011. MIROC-ESM 2010: model description and basic results of CMIP5-20c3m experiments. Geosci. Model Dev. 4(4): 845-872, doi: 10.5194/gmd-4-845-2011.

Williams AP, Allen CD, Millar CI, Swetnam TW, Michaelsen J, Still CJ, Leavitt SW. 2010. Forest responses to increasing aridity and warmth in the southwestern United States. Proc. Natl. Acad. Sci. U. S. A. 107(50): 21289-21294, doi: 10.1073/pnas.0914211107.

Wu SH, Yin YH, Zheng D, Yang QY. 2006. Moisture conditions and climate trends in China during the period 1971-2000. Int. J. Climatol. 26(2): 193-206, doi: 10.1002/Joc. 1245.

Xing WQ, Wang WG, Shao QX, Peng SZ, Yu ZB, Yong B, Taylor J. 2014. Changes of reference evapotranspiration in the Haihe River Basin: Present observations and future projection from climatic variables through multi-model ensemble. Global Planet Change 115: 1-15, doi: 10.1016/j.gloplacha.2014.01.004

Xu CY, Gong LB, Jiang T, Chen DL, Singh VP. 2006. Analysis of spatial distribution and temporal trend of reference evapotranspiration and pan evaporation in Changjiang (Yangtze River) catchment. J. Hydrol. 327(1-2): 81-93, doi: 10.1016/j.jhydrol.2005.11.029.

Xu YP, Pan SL, Fu GT, Tian Y, Zhang XJ. 2014. Future potential evapotranspiration changes and contribution analysis in Zhejiang Province, East China. J. Geophys. Res. Atmos. 119(5): 2174-2192, doi: 10.1002/2013JD021245.

Yin YH, Wu SH, Zheng D, Yang QY. 2008. Radiation calibration of FAO56 Penman-Monteith model to estimate reference crop evapotranspiration in China. Agr. Water Manage 95: 77-84, doi: 10.1016/j.agwat.2007.09.002.

Yin YH, Wu SH, Chen G, Dai EF. 2010. Attribution analyses of potential evapotranspiration changes in China since the 1960s. Theor. Appl. Climatol. 101(1-2): 19-28, doi: 10.1007/s00704-0090197-7.

Zheng D. 1999. A study on the eco-geographic regional system of China. FAO FRA2000 Global Ecological ZoninWorkshop, Cambridge, UK.

Zheng JY, Bian JJ, Ge QS, Hao ZX, Yin YH, Liao Y. 2013. The climate regionalization in China for 1981-2010. Chin. Sci. Bull. 58(30): 3088-3099, doi: 10.1360/972012-1491. 